\title{
Scaffolding and Synergy in English Teaching by Native and Non- Native Educators: A Study in an EFL Context in Colombia
}

By William Ricardo Ortiz García \& Carol Anne Ochoa Alpala

Universidad Santo Tomás

Abstract- This paper shows the results about a qualitative research project focused on the analysis of three juxtaposed points of view about the perceptions regarding the teaching of English guided by native and non-native educators in a private university in Colombia. This study is based on the theoretical framework and concepts related to the nature of native or non-native educators with a methodology and analysis of the three perspectives: students, a native educator and a non-native educator, their opinions and experiences are contrasted to determine the academic positions and points of view of each of the parties involved, in order to understand how to achieve a more meaningful learning process. A questionnaire, an interview and a professor's journal were used to collect information in this case study research.

Keywords: scaffolding, synergy, EFL, native, non-native, teaching.

GJHSS-G Classification: FOR Code: 420101

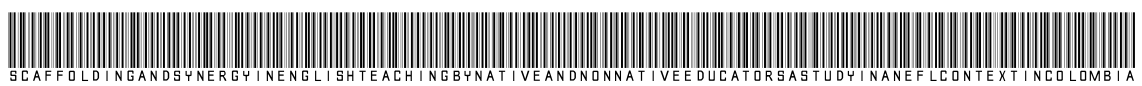

Strictly as per the compliance and regulations of:

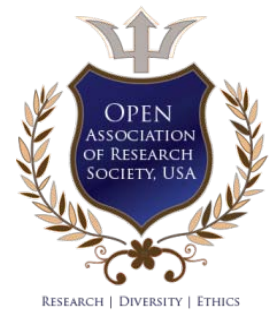

(C) 2019. William Ricardo Ortiz García \& Carol Anne Ochoa Alpala. This is a research/review paper, distributed under the terms of the Creative Commons Attribution-Noncommercial 3.0 Unported License http://creativecommons.org/licenses/by-nc/3.0/), permitting all non-commercial use, distribution, and reproduction in any medium, provided the original work is properly cited. 


\title{
Scaffolding and Synergy in English Teaching by Native and Non-Native Educators: A Study in an EFL Context in Colombia
}

\author{
El Andamiaje Y Sinergia en La Enseñanza del Inglés Impartida por Docentes \\ Nativos Y no Nativos: Un Estudio en un Contexto de Enseñanza de Inglés Como \\ Lengua Extranjera En Colombia.
}

William Ricardo Ortiz García ${ }^{\alpha}$ \& Carol Anne Ochoa Alpala ${ }^{\circ}$

Resumen- Este artículo versa sobre los resultados de una investigación cualitativa enfocada en el análisis de tres puntos de vista yuxtapuestos en torno a las percepciones acerca de la enseñanza del inglés orientada por docentes nativos y no nativos en una universidad privada en Colombia. Este estudio se basa a partir del marco teórico y de conceptos en relación con la naturaleza de docente de lengua nativa o de lengua no nativa y con una metodología y análisis de las tres perspectivas: estudiantes, un docente nativo y un docente no nativo, sus opiniones y experiencias son contrastadas para determinar las posturas académicas de cada una de las partes implicadas con el propósito de entender cómo se consigue un proceso de aprendizaje más significativo. Un cuestionario, una entrevista y el diario del profesor fueron instrumentos utilizados para la recolección de datos. Los resultados enfatizan que los estudiantes piensan que las ventajas del docente nativo son las desventajas del docente no nativo y viceversa, los estudiantes consideran que mejoran sus habilidades de habla y escucha con docentes nativos mientras que la lectura y escritura se desarrollan mejor con docentes no nativos. Los estudiantes no creen que exista una dicotomía sino un proceso recíproco.

Palabrasclaves: andamiaje, sinergia, EFL, nativos, nonativos, enseñanza.

Abstract- This paper shows the results about a qualitative research project focused on the analysis of three juxtaposed points of view about the perceptions regarding the teaching of English guided by native and non-native educators in a private university in Colombia. This study is based on the theoretical framework and concepts related to the nature of native or nonnative educators with a methodology and analysis of the three perspectives: students, a native educator and a non-native educator, their opinions and experiences are contrasted to determine the academic positions and points of view of each of the parties involved, in order to understand how to achieve a more meaningful learning process. A questionnaire, an interview and a professor's journal were used to collect information in this case study research. Findings showed that student think that the advantages of the native educators is the disadvantage of the non-native educators and vice-versa, students reflected about the classes taught by native educators as positive in terms of making up the abilities of speaking and listening while they considered that they improved the abilities of reading and writing guided by non-

Author $\alpha \sigma$ : Universidad Santo Tomás, Tunja, Colombia. e-mails: rishoortiz@gmail.com, carol.ochoa@usantoto.edu.co native educators. Students do not think there is not a dichotomy but a reciprocal process.

Keywords: scaffolding, synergy, EFL, native, non-native, teaching.

\section{INTRODUCTION}

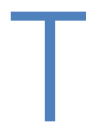
his work seeks to offer new horizons in the future pedagogical practices currently carried out in the field of English-teaching as a foreign language in different learning contexts. As it is currently well-known, becoming proficient in more than one language has ceased to be a value-added for learners and has instead become essential to access a variety of new achievements: to receive promotions, earn higher incomes, and get scholarships for post-graduate studies, among others. English as a foreign language is one of the most important pillars in the academic processes carried out by educational institutions, which seek to train professionals and students that are increasingly competent in the working world. Undoubtedly, learning a language is a fundamental part of this training. This research was conducted with students of native and non-native language educators at a private, denominational university in the department of Boyacá, Colombia. English is the particular focus of this paper, as it is one of the most spoken languages in the world. Likewise, the voices of the educators and the way they conceive of the processes carried out in their classes are included so that the narrative is complemented by more than one point of view and provides information from diverse, reliable sources.

Listening to the voices of English students paints a fuller picture of their perceptions and experiences, which contribute to the understanding and analysis of the factors involved in improving and understanding the educators' practices objectively in this language, based on results from a primary source rather than guesswork or theory. Moreover, in this type of research it is important to consider the points of view of both native and non-native educators to achieve a broader and more objective perspective of the learning 
process as a foreign language. Conducting this investigation is of professional interest to the authors, as through it, they seek to understand and analyze various points of view and experiences of students regarding academic processes with native and non-native educators alike, with the purpose of changing educational practices and promoting meaningful learning in English classes.

\section{Problem and Research Questions}

According to an informal poll conducted on the student population of the Universidad Santo Tomás in Tunja, Boyacá, Colombia (USTA), a portion of students believe that taking classes from a native speaker is optimal, while others in the same population maintain that they learn better from non-native professors. Likewise, some students believe that native and nonnative professors complement each other. For that reason, it is necessary to thoroughly investigate the perceptions and experiences that students have toward learning English as a foreign language, to objectively understand their results with the language, and determine why they take a specific, fixed stance towards native and non-native professors and believe that teaching by these types of educators is more effective or meaningful. Additionally, the opinions of these types of professors must be heard. Based on the above, the following research questions arise:

Within the population of intermediate students' level of English as a foreign language at the Universidad Santo Tomás, Tunja, Colombia, what are students' assumptions of classes given by native and non-native professors?

How do native and non-native English professors describe the experiences of students in their classes?

\section{ili. Objectives}

a) General objectives

i. To analyze perceptions and assumptions of classes given by native and non-native English educators in USTA (Universidad Santo Tomás, Tunja) within the population of intermediate students' level of English as a foreign language at the Universidad Santo Tomás, Tunja, Colombia.

ii. To reveal the opinions of both a non-native professor and of a native English-speaking educator toward the processes of teaching a foreign language, as well as their experiences with the students.

b) Specific objectives

i. To contrast students' experiences of their process of learning English as a foreign language between those carried out by native and non-native educators. ii. To analyze the implications of taking classes with native and non-native professors from the point of view of the educators in question.

\section{Theoretical Background}

In this research, the theoretical framework is related to each aspect of the process of teaching English as a foreign language by native and non-native professors within a local, national, and international context. These contexts generate open spaces for the discussion of best practices to carry out the process of teaching and learning in said language.

\section{a) Implications of being a native language educator}

The following is a description of the theoretical approach of the native language professor and its conception according to various sources.

A native English educator is defined as an educator who teaches a language $(L 1)$ as a second language or foreign language. At this point, it is necessary to make a distinction between L2 (second language) and FL (foreign language). In the first case, the language is spoken in the community in which one lives, even though it is not the learner's native language, while in the second case, the language does not have a presence in the community where the learner lives (Muñoz, 2002).

Likewise, as expressed by other authors and specifically by Gargallo Santos cited by Manga (2008): "Second Language (L2): That which fulfills a social and institutional function in the linguistic community in which it is learned. Foreign Language (FL): That which is learned in a context in which it lacks a social and institutional function" (par. 9). In the Colombian context, English is taught as a foreign language, given that said social function presented by the author is not fulfilled in the national territory.

Undeniably, there are benefits to receiving classes from native professors. These include but are not limited to the fact that they can contribute to significant language-learning in terms of deep knowledge of the language and linguistic competency, or "the appropriate idiomatic use of the language, cultural connotations and the ability to evaluate when a linguistic structure is appropriate or not" (Phillipson cited by Peraza, Saulny, Arrioj, \& Cruz, 2012, par. 10). Likewise, native speakers provide a closer approximation to their culture, since they are familiar with it and can convey a better understanding of it than a non-native speaker could.

\section{b) Implications of being a non-native educator}

A non-native language professor is defined as a person whose L1 is not English, but who has received academic and pedagogical training that qualifies them for teaching English as a foreign language. 
Some studies carried out in this field, such as that of Lasagabaster \&amp; Sierra (2005) reveal that some university students in Spain prefer native speakers for concrete points such as pronunciation and development of speaking and listening abilities, but not for vocabulary or grammar, because "sometimes they do not have the knowledge to explain it" (p. 363).

On the other hand, a study of Mahboob cited by Walkinshaw \&amp; Hoang (2014) shows that non-native educators are at a disadvantage because of limited oral competency and little understanding of the culture. Despite their methodology and hard work, the above can be understood as the Achille's heel of educators whose L1 is not English. Paikeday (2005) describes "the recognition of the native educator as the principal authority in linguistic correction" (p. 391) stemming from their status as native speakers is seen as reliable. Thus, this belief that the native speaker is a superior English educator has been long-held.

In the same line of analysis, a student can feel the close accompaniment with their non-native educator, since they will have the empathy necessary to understand the difficulties that may arise in the learning of a language and provide them with meaningful assistance, which can help the student to improve their own language-acquisition process.

According to research conducted by Murray, Park, Kachru, Kamhi-Stein, \&amp; McKay, among others and cited by Peraza et al (2012), "the profession benefits if it considers the competency that a professor has to develop in the students the four skills (written and auditory comprehension, written and oral production)" (par. 8). In this research, the development of speaking is not taken as the only learning pattern, but rather as one of the four skills that one should develop in the learning of a foreign language to be a well-rounded process.

\section{c) Teaching English as a Foreign Language}

There is no standard pattern showing that the teaching of English as a foreign language should be taught in $\mathrm{X}$ or $\mathrm{Y}$ manner for successful learning, so the methods, strategies, and focuses used depend on their specific context and results. These previously mentioned aspects continue to be used in English classes. On the other hand, it should again be highlighted that not all methods work in all contexts. Different methods are used, new studies are implemented, and learning processes are carried out in different forms. In the concrete case of Colombia, the study of English as a foreign language is regulated by relevant laws. The Ministry of Education's efforts to improve said processes include linking native speakers that contribute to the language education in question, especially in the official sector. In the private sector, they are more confident in other factors to support the language-learning process: they simultaneously reinforce a more time-intensive English schedule (depending on the educational institution and its academic focus); diverse printed materials, like books; virtual platforms; educators qualified in foreign languages that have, at a minimum, a proficiency supported by international exams accepted by the Common European Framework of Reference for Languages, such as TOEFL; among other strategies, such as the inclusion of the target language in an interdisciplinary manner in other classes

d) Parameters and standards established by the national Ministry of Education (MEN) of Colombia in the teaching of English as a foreign language

Currently, in Colombia, the curriculum guidelines for the teaching of English as a foreign language are defined in law 115 of the constitution of 1994. Within the processes advanced in Colombia, the national Ministry of Education (MEN) laid out guide no. 22: "Basic Competency Standards in Foreign Languages: English" which goes into operation with the basic standards of competency in language, sciences, and citizenship. As a result, the MEN proposed the national bilingualism program with the objective of training competent students according to international standards.

According to the plan laid out by the MEN of Colombia, the levels of achievement in English are divided by academic years in which educational institutions are supposed to work on each level of the Common European Framework of Reference. The target levels are explicitly laid out in the document Visión Colombia 2019, (Guide No. 22 Basic Competency Standards in Foreign Languages: English. Training in foreign languages: The challenge!, English standards part 1, p. 10) in the following manner:

- From first to third grade in primary school: Level A1 MCE (beginner).

- From fourth to fifth grade in primary school: Level A2 (A2.1) MCE (basic 1)

- From sixth to seventh grade in secondary school: Level A2 (A2.2.2.) MCE (basic 2)

- From eighth to ninth grade in secondary school: Level B1 (B1.1.) MCE (pre-intermediate 1)

- From tenth to eleventh grade in secondary school: Level B1 (B.1.2) MCE (pre-intermediate 2)

- The previously mentioned report also inspired the use of declarative knowledge, skills and abilities, personal knowledge, and the ability to learn in English classes.

\section{Methodology}

This research is qualitative. Qualitative research is widely considered to be "that which produces descriptive data: people's own spoken or written words and their observable conduct" (p. 48). 
Throughout this research, a theory in which a descriptive method is used is shown. It seeks to determine and analyze the perceptions and contrast the experiences of law students in the Santo Tomás University in Tunja, Colombia in relation to English as a foreign language classes guided by native and nonnative educators. The information collected is a description of their thoughts, perceptions, experiences and points of view. Additionally, two educators (one non-native and one native speaker) are interviewed in order to get to know their points of view and incorporate three distinct, complementary, and significant voices on the subject of the processes of learning English as a foreign language. Native and non-native educators have worked at Universidad Santo Tomás in Tunja for more than five years, the native one has a diploma as professional and some certifications in educational issues and the non-native one studied for five years to get a diploma as an English teacher, that educator also studied two masters in English teaching as a foreign language and has a TOEFL certification in C1.

At the same time, this research includes a case study. Some authors, such as Yin Cited by Martínez (2006) maintain that "the case study method is a very useful research tool, and its greatest strength is rooted in the fact that the behavior of the people involved in the phenomenon studied is measured and registered "(p. 67).

The population selected for this research consisted of 20 undergraduate students in the law department, a non-native English educator and a native English educator in the Santo Tomás University in Tunja, Colombia. The participants of this project are 20 intermediate English level students from law faculty at USTA, Tunja. Students from this faculty need to take 9 English courses, for this reason, they are willing to participate in this kind of research inasmuch as they deal with English class within their undergraduate program. Their ages ranged from nineteen and twentytwo years old. There were 12 women and 8 men. The sample was selected considering the circumstances that the students in the class had experienced and the opportunity to take English as a foreign language classes given by native and non-native educators more than once per each educator. The participants were informed about their voluntary participation in the development of the project, in the same way; they signed a consent form in which they claimed their free and spontaneous participation of this research. Students' voices were included using the capital letter of their names.

\section{a) Instruments}

\section{i. Questionnaire}

Over time, a questionnaire has been one of the most-used instruments to conduct diverse research. For this reason, some authors have noted that the questionnaire is:

"an instrument that is typically associated with quantitative focuses and research designs, because it is constructed to contrast points of view, because it favors contact with nomothetic rather than ideographic forms of knowledge." (Rodríguez, Gil, \& García cited by memory of investigation. s.f. p. 56).

\section{ii. The Interview}

The interview was another instrument used for data collection. It is considered to be a "technique oriented to obtain information in an oral and personalized form about lived experiences and subjective aspects of the respondents in relation to the situation that is being studied" (Folgueiras cited by Cáceres, 2014, p. 36). The interview used for this research was designed to be semi-structured with open, precise, and pre-written questions to be given in a set order, in such a way that students could complement the responses that they had given when the questionnaire was administered.

\section{iii. Professor's Journal}

This is an instrument that is generally used as part of pedagogical research carried out by educators to investigate students' practices. One of the possible uses of the journal is similar in manner to a type of questionnaire, known as selection, that is structured by the educator (Korthagen, 2013). A non-structured journal was used for the research at hand. The researcher took notes when they had the opportunity to do so during classes and in the execution of worksheets and different activities, including oral and grammatical exercises. The journal was carried for three months.

\section{b) Method of Analysis}

The information of the project was collected with the previously mentioned instruments in mind: on the one hand, the survey; on the other, the interview, and finally the professor's journal. These methods were analyzed in light of grounded theory, which is an approach to the development of the theory that is "grounded in the collection and analysis of systematic data." This theory involves what has been called constant comparative analysis. In it, the researcher must be equally immersed in the collection of both inside and outside data collection and analysis (Strauss \& Corbin, 1994).

\section{c) Results}

i. Process of English as a foreign language class taught by native educators and its implications: student experiences

This research shows the students' points of view, as much from the process as from the lived experiences during these English as a foreign language classes. 
Native educators of foreign languages have always benefitted from popularity among educational institutes and people that consider learning from a native speaker to be the best and most authentic way to learn. As a consequence, said educators tended/tend to be seen as a legitimate linguistic model for the teaching and learning of English as a foreign language (Kachru, 1992) cited by (Chacón \& Pérez, 2009, p. 50). The native educators are those how L1 (first language) is English which, in the educational context in which the present research is framed, is taught as a foreign language (FL). In the same way, this research illustrates the process carried out by twenty students in English level five, in the law department in the Universidad Santo Tomás, Tunja, who have received classes guided by native professors. This research shows the students' points of view, as much from the process as from the lived experiences during these English as a foreign language classes.

In this way, the students point out that having received classes guided by native speakers, about $85 \%$ of them are observed to be aware of the benefits of having native educators, and have expressed this in class throughout the different activities proposed by the educator. These comments are registered in the professor's journal.

In particular, students highlight the pronunciation in its natural state, and in this way justify during their exercises the development of their oral ability (speaking), in which students like to ask their native educators the correct pronunciation of words and some terms and idiomatic expressions. These students see these educators as a dependable source of the way to speak English correctly and feel certain that they are developing this ability in an authentic way since they have a standard, adequate model to carry out this activity. On the other hand, they state that they learn from the knowledge that these educators contribute about their culture, clarification of doubts, and cultural details that they can learn. For example, native speakers can teach sayings, colloquial forms, expressions, phrases, and ways to distinguish between different English dialects. Native speakers certainly represent an authentic way to be contact with a culture without being immersed in it. The remaining 15\% demonstrate their indifference for their educators' place of origin. This small portion of students values other matters, such as methodologies, didactics, and pedagogies that can be used to learn said language. Consequently, they do not see the nativeness as a unique, necessary, or exclusive source of success in the language-learning process. They even cite that their learning process is subject to diverse factors, such as the materials used in class, the time intensity of the week, the quantity of activities that they can develop with the goal of practicing what they have learned, the spaces available for classes, and the intrinsic interest of the student and their own motivation to want to learn English. Although the students are conscious of the fact that native speakers can contribute in these areas, they make clear that they have problems with their methodologies and the way the class is given. Students feel that non-native educators do not quite fit in the national context, generating the feeling of a lack of communication and leading to them not completely understanding the topics.

The students were interviewed and questioned about the implications of receiving classes from native educators and some of the students responded in the following manner:

I: From your point of view, what do you consider to be the implications of receiving English classes given by native educators in the USTA? Support your response.

A.T. "The implications with a native speaker can be that they help us to understand their culture better and they can offer more information from their vocabulary, to listen, and to pay more attention to other details that we can use in another situation, and of course, the pronunciation; on the other hand, the native educators are not very contextualized in our culture, and in this case, they lack methodology, because the educational systems are different." Interview excerpt.

M.G. "Well, the implications with a native educator is that they can teach us more about their culture and also about how they speak and pronounce English in their country, but due to their methodology, the ideas do not always come across clearly and are not always understood, and the pronunciation can be complicated." Interview excerpt.

L.M. "The implications of receiving classes with a native is that one learns more of the pronunciation and the vocabulary of the language, however they do not have the methodology for us to quickly learn because of cultural differences, because they might lack knowledge about our culture and how to make us learn the language well." Questionnaire excerpt.

G.G. "The implications of a native professor is that sometimes, they do not understand our needs well and their methodology is different from the way we can understand English better." Questionnaire excerpt.

In the above excerpts of the interview and the questionnaire, the students state that the greatest benefit of receiving classes with native educators is undoubtedly rooted in their pronunciation and the way that they teach the culture of English-speaking countries in a more authentic way. Approximately $35 \%$ of the participating students describe their experiences as a good learning process and value the concrete aspects that native educators bring, such as the learning of pronunciation, fluency, expressions particular to the language, and the way the content was approached. The students stated that they highly value the patience 
that their educators showed and the didactics used in their classes, and moreover, the advantage of the time to develop their listening ability, which benefits them and improves their pronunciation. The students believe that contextualizing the language is simpler with a native speaker, since they may have a clearer idea of why aspects of the language are the way they are, and state that learning concrete things like sayings, phrases, colloquial forms, and expressions of the language gives them a deeper understanding of the language they are learning.

On the other hand, $45 \%$ of the students claim not to have had a good experience in classes given by said educators. They argue that, based in many of their experiences, the native educators do not understand the social context in which they are carrying out their classes and as a result, they teach the topics in an overly-complex way, which naturally does not result in an adequate understanding of the topics. Moreover, they perceive non-native educators' classes as nonlinear, in both the way that they teach classes and in how they develop thematic content. As a result, the students naturally become confused and do not understand the topic. Due to the lack of contextualization in the national environment, it is difficult for native speakers to interact with the students, who, in turn, cite not having a clear line of communication with their educator and simply ignore their own questions and doubts as a result. The learning process is therefore truncated and generally not completely successful. The students describe their process with the native educators as slightly inefficient. Similarly, they argue that they do not feel that native educators prepare their classes; on the contrary, there is a high level of improvisation because of native educators have no problems with speaking target language.

$10 \%$ of the students qualify their process with native educators as "fair," feeling that even native speakers lack both the understanding of the national culture necessary to understand the needs of the students and an efficient way to cover the content. They also affirm that on some occasions, the native educator does not reflect on whether the students have enough time to internalize the topics, and as a result, students feel that they do not have the tools they need to develop their foreign-language abilities. Students also perceive a lack of preparation from non-native educators, and point out that the methodologies are not correct or adequate for the context in which the class is given. Finally, the remaining $10 \%$ describe their experiences as something new, but not very significant: they did not find that having a native educator deepened their languagelearning or make them feel that they were learning meaningfully. On the contrary, they felt that it was just another class that could be given by anybody, without the educator's native background bringing any added value to the course.

In both the interview and in the questionnaire, the students maintain a position based in their experiences, about $35 \%$ of the time, the native educators bring very limited knowledge to the Englishlearning process. They think, and argue, that there are matters more important than pronunciation: while many of them claim that this is the principal strength of a native educator, it is not the only relevant factor: different English abilities deserve equal attention.

ii. Process of English as a foreign language class given by non-native educators and its implications: student experiences

The non-native English educator is that whose L1 (first language) is not English, but has received training at a university level to be able to teach it, especially in contexts where this language is taken as a foreign language. Lakatos \& Ubach (1995, p. 242) identify the key problems in the teaching of said language by non-native educators as the level of mastery of the language and culture is inferior compared to native educators. For these reasons, nonnative educators are perceived as being worse at teaching said language, and the belief that non-native educators are not well-qualified to successfully carry out this task persists. However, it is long overdue that positive aspects of non-native educators are being recognized. For example, Lakatos \& Ubach (1995, p. 242) affirm that the non-native speaker can offer a learning model for the student, in which other qualities of these educators are emphasized at the time that they give class, for example their didactics and determination that they show to carry out their work in the best way possible.

The participants in this project, through their lived experiences with non-native educators, have had the possibility to broaden their opinion. Likewise, the professor made notes in the journal based on these experiences and expresses their points of view in the following way:

$90 \%$ of the students claim to have had very good experiences with their non-native educators, arguing that, since the educators have gone through the same learning experience, they are more conscious of the fallacies that students might have and can explain and clarify topics efficiently; they affirm that the nonnative educators are more patient, and thus their learning process is significantly enriched. Likewise, they explain that for these reasons, non-native educators are more demanding, because being familiar with the culture allows them to envision how far their students can go and to impose new challenges, choose evaluative processes according to their level and 
characteristics. Non-native educators know that not everyone is in the same condition and their performance can be tainted by different circumstances such as the lack of support or of opportune pedagogical interventions, circumstances that can be analyzed or foreseen by knowing the national context in which one is giving classes. Non-native educators have a valueadded in their ability to interpret of gestures or attitudes of the learners; because they share customs, they can perceive things in the process of the students. For example, they can tell when students do not completely understand or an explanation is not clear without having to be told explicitly.

The remaining $10 \%$ believe that non-native educators show fallacies such as not giving classes completely in English and they see this as a disadvantage, since this does not promote the development of fluid speaking, but understand that on some occasions the intervention of the mother tongue is necessary to clarify different aspects, which naturally helps students to clearly understand topics. Additionally, they think that not hearing the original pronunciation of the foreign language as it is being taught is a disadvantage.

Likewise, the professor's journal reflects a good participation in the activities carried out in class on the part of the students, as the ability to use both languages (if necessary), gives them security as they participate, and simultaneously allows them not to feel selfconscious, because knowing that when they do not have enough vocabulary, they can rely on their first language, and it will be a great help.

In the same way, the students find that nonnative educators have methodologies that are more in line with their needs in terms of the explanation of content, the way that they can practice, and the knowledge of the culture in which they are teaching English as a foreign language. In other words, the knowledge of the social context causes them to search for and make use of different alternatives so that the students successfully absorb the topics, or at least try to find new alternatives to that end.

The students were asked about their experiences in classes with non-native educators and here they present their responses:

I: How would you describe your learning process guided by a non-native educator at USTA?

A.T.: "My learning process has progressed, since I do not take into account where the educators are from so one must have in mind the education that they provide to us, or the methodology has to be done more in line with our needs and I think that yes they have achieved that." Interview excerpt.

L.R. "The process with the non-native educator has been very good, because in some cases, the professor understands and discloses to the student his or her shortcomings, which is what is really needed to reinforce that in each of his or her classes." Interview excerpt.

M.V. "The process with a non-native is good, since we come from the same culture and they better understand what our needs are. It is not simply the pronunciation, but knowing why things are the way they are, for example what the verb tenses are used for." Interview excerpt.

M.J.V. "Well it depends on the professor; some try to make the student learn and there are others that make everything easy for the students and don't allow the student to develop their academic level in English".

O.A. "My position with the professors that were born here is that they make the classes educational and try to teach us, and beyond that, they know the reality we live in and know our words, and about the historical context of that country with this country. It is a little bad because you cannot learn the original pronunciation of the language, but every so they try to improve the social context that we live in to have a good vocabulary".

In the above excerpts from both the interview and the questionnaire, the students claim that the process carried out with non-native educators has been good. In turn, they value the methodologies used in class in order to understand the topics and cover all of the content, through the methodologies that the students find useful and that work for them.

$85 \%$ of the students claim that they learn better with non-native educators and insist that these educators find a practical way to teach English in a way that is significant for the students.

By the same token, this high percentage of students value the effort of their educators and describe the classes as a space in which, beyond learning effectively, they can interact with the educators. When there is a channel of communication, students feel that they can find out their shortcomings and how to work on them; since the non-native educator has more empathy for the students' process and can easily put himself in their shoes and understand that the process needs to be reinforced through diverse activities. They also point out that they feel there is good organization and planning that clearly establishes the goal of each class.

The remaining $15 \%$ of students have other opinions related to poor and fair experiences. They feel that non-native educators to not give them an extrinsic motivation to take the class more seriously; they affirm that they do not feel motivated by the attitudes of the non-native educators (as they do not give the necessary importance to the class or, on the other hand, can become too lenient using the excuse that they understand that the process is complex and so they cannot demand as much as they should), in addition to a series of other factors such as not feeling that the speaking is genuine or that the educator's competence is not satisfactory according to their expectations, based 
on criteria presented by Mahboob's (2003) cited by (Walkinshaw \& Hoang, 2014, p. 3), in which the authors maintain that some non-native educators have low oral competency and limited cultural knowledge as disadvantages; these factors are decisive for this last portion of students in their English classes.

However, the law students in English as a foreign language level five in USTA describe in their interviews and questions being immersed in a reciprocal process, where they can expect results based not solely on the their educator's native language, given that they have an intrinsic motivation and desire to learn a foreign language, that the educator is an important factor since "from my point of view they are the most important factor, if they are demanding and help students understand well, the process will be successful, and additionally they bring other factors such as the materials (because they design their class), the didactic resources, among others, and therefore they seem very important to me and more than anything to know how to select them." Interview excerpt, but that definitely, they also should be committed, finally it is their process which is at stake, which either benefits or stagnates.

iii. Teaching-learning process of English as a foreign language and implications for students from the point of view of native and non-native educators

Currently, the educational institutions both in the public sector and in the private sector of the country are looking for the way to include native and non-native English educators on their payroll. In the public sector, the ministry of education has focused on bilingualism with the inclusion of native speakers as support in English classes. In the private sector, they have included native speakers as part of the faculty. Said educators have academic training to teach the class a foreign language or a second language, although not all the educators have been trained pedagogically to that end, so being a native speaker is considered to be a sufficient qualification to give English classes.

On the other hand, non-native English educators, who are professionals with a university degree from a five-year program. Institutions of higher education require that non-native educators have postgraduate studies, including a master's degree, and that their level of English is certified to be at least $\mathrm{C} 1$ through international exams.

The university at hand has both native and nonnative English educators, who were interviewed about the processes carried out in English class with undergraduate students and that have received classes taught by both.

As part of the data-collection, with the goal of knowing their points of view as they relate to their perceptions regarding the teaching-learning process of English, two educators were interviewed: one native speaker, "NE," and one non-native speaker, "NNE," who make their assessments in the following way:

What is your perception of the classes given by native speakers and non-native speakers at USTA Tunja?

$\mathrm{NE}$ : I think that we have an advantage with respect to the culture here in Colombia and I think that the people want to have native educators because they think that it is better, because of the pronunciation and the knowledge of the culture and I think that they, the students, think this way but they don't think of the similarities between Spanish and English, which the nonnative speakers know better than us, right? $\{\ldots\}$

$\{\ldots\}$ when I enter into a classroom, the students don't stop to think whether or not I have the ability to speak English well and with non-native educator, well, they do $\{\ldots\}$

NNE: Well, I have always thought that having native professors and non-native professors in a team is fundamental... and we can have a complementary relationship, where we help the native speakers to understand our Colombian culture and, consequently, they can communicate with the students in a more meaningful way. Ehhh, I am not unaware of the fact that we must study many more years and permanently study the foreign language together with foreign cultures that are not part of our broad or extensive knowledge $\{\ldots\}$

The native educator reaffirms what was previously mentioned by the students, who value and hold in high esteem to English speaking ability, in its native form, a reliable source to learn pronunciation and improve aspects such as fluency and comprehension. The NE is also conscious of the fact that knowledge of English culture brings a value-added to the performance in class, since being an expert in this field, a native speaker can give exact responses to questions that come up in the middle of class. This educator also makes the assessment that, although the students do not see it this way, the native educator sees it as an advantage to be familiar with both cultures to facilitate the learning process. On the other hand, the non-native educator reflects on the importance of having both types of educators, and consequently does not perceive being a non-native speaker as a disadvantage compared to the native speaker, although the NNE is conscious of the fact that one always must work to improve, and on the contrary, in this last point the NNE finds that the relationship can be complementary as a reciprocal collaboration to improve aspects of their performance, rather than empowering or elevating one over the other. The NNE also reflects on the relationship as an enriching learning and teaching experience, since with the required effort, a NNE can overcome the obstacles that could in some way limit performance. To this last point NNE puts forward: [...] however, it is 
possible that a non-native English educator could achieve a level of language ability and cultural knowledge which is so high... that... ehh, the line between native and non-native could become almost imperceptible. This while recognizing that the advantages of native speakers can be our disadvantages and vice versa $[\ldots]$

This educator clarifies that with the necessary preparation, the native or nonnative character will not be a resource that defines success in the process of English teaching, turning it into a strict dichotomy between which one must choose. The NNE recognizes that in each of the types of educators there are both advantages and disadvantages but finds that the duality in the advantages of one could be disadvantages for the other and vice versa. On the other hand, the native educator notes the following: NE [...] but I think that after the first month there is no difference in learning between natives and non-natives, because what is important in the class is the quality of the class, the quality of the materials, the quality of the explanation, how you want to behave in class, your tone of voice, your mood, everything, right? So after a while there is not difference, the process is the same, right? Very soon for the student it's not whether or not you're a native speaker: it is that you are the professors and the professor has to meet some requirements with the student's mental image of a professor $\{\ldots\}$

On this point we can find a situation like the breaking of the native vs non-native paradigm, since as NE states explicitly, learning is not measured only by its nativeness as such, but also by a series of factors that come into play and, in one way or another, influence the learning of the language. These include materials, the quality of the explanations, and even the mood of the educator, demonstrating other possible facts that can contribute to the success of this process. Therefore, we can start to understand that the two types of educators are conscious of the responsibility to which their performance gives rise, and beyond being a native or non-native educator, concentrate on the fact that the required preparation is fundamental to take on the challenge of teaching in class.

In the interview, the aforementioned educators reflect on the learning processes that they guided to analyze them in their own point of view.

How would you describe the teaching process guided by native and non-native educators at USTA Tunja?

NE $\{\ldots\}$ I think that as a native speaker I have some opportunities, two or three more, to show or to demonstrate that yes, I am a good professor or not, and that because I am something new, I am an experience for them because I am a native educator, and this does have a small effect at the beginning, but very soon, as a professor you need to show your personality, show that you want to have the class, that you are truly strict or not and as a professor yes, I have this advantage that I am something new $\{\ldots\}$

This educator believes that being a native speaker undoubtedly represents an advantage for yes in terms of novelty and motivation for the students, since they can feel persuaded to learn, although the NE also knows that moving forward, results that determine that the native language is a benefit in the English-learning process will need to be shown. In the same way, NNE claims: I believe that native and non-native educators can become very good in their teaching duties, however, one must consider that both of us have an obligation that has repercussions in the teaching-learning process of English as a second language. Well, for the non-native educators it is fundamental to keep studying the foreign language, since if you don't practice it, it's lost. It is a permanent practice.

This last educator points out that success is not necessarily rooted in being a native speaker or not, and both can become good at their profession, just as both could fail to be successful at it. The responsibility is based on the fact that an adequate preparation, which is not exclusively rooted in the pedagogical training, since according to NNE: It is not enough to major in pedagogy to teach students a language; it's necessary to search for the deepest understanding of the language and if it is possible, live in the foreign culture or study it, keeping in contact with authentic material and with native educators, you can teach us a lot about your culture $\{\ldots\}$ consequently, continuing with the preconceived notion that the educator's nativeness is a circumstantial point, and as would can understand, it has advantages, but is not the only point that is taken as a frame of reference in successful learning.

NNE: On the other hand, to a foreigner, a native English speaker, it is not enough to come to his or her country to take on a role as an educator for something that he or she hasn't studied, the ministry of education should understand that to achieve a bilingual Colombia, the foreigners that come to teach their language and culture to our students should have a base in pedagogy and know how the educational process works, not just in their countries, but also the Colombian educational system.

These points converge throughout the process, naturally each one of the educators in question knows the advantages that they try to use to their favor, and also know that there are points that could be improved $\mathrm{NE}\{\ldots\}$ honestly we don't have the experience of the non-native professors and it is one thing to know how to say, "I don't know," and another thing is to explain, I think that non-native professors have to show a lot more, maybe you need to know better than us, because you have a disadvantage: not knowing English as a mother tongue $\{\ldots\}$ 
In this case, the native educator recognizes the advantages and disadvantages of being a native speaker, knowing that these are on the agenda and that at some point the NE will take on each of these without letting performance be diminished. On the part of the other educator, the NNE is more conscious of the reality, especially because the national system has let the NNE see that challenges in the classroom are more difficult for a non-native speaker, however, this educator recognizes in the dichotomy a variety of possibilities, with advantages and disadvantages, and also recognizes that one of the principle challenges for NNEs is based in the need to prove that one is qualified to teach the subject in a compelling way, with good results and great possibilities of success. This is not to say that the NNE believes that by not being a native educator, the mastery of the language cannot be sufficient; especially when the English level, pedagogical knowledge, and the ability to guide English classes in a successful way are certified.

\section{Vi. Conclusions}

The experiences that undergraduate law students have had in classes given by native educators have as often been good as they have been average, the reasons for which are related with the way that said educators lack an understanding of the culture in which classes are given; on the one hand, some describe their experiences as good in terms of having classes with a native educator being something novel, and they feel that they can learn pronunciation in an optimal way. On the other hand, the bad experiences come because of the lack of methodology and apt didactics for their learning according to the students' needs and feel that their process improves progressively, a small percentage have not had good experiences with the non-native educators, since they feel that they do not motivate them to learn the language and don't have a genuine pronunciation of the language.

Once the students experiences are determined and contrasted, one can conclude that the student perceive that the advantages of the native educators is the disadvantage of the non-native educators and viceversa; on the one hand, the students think that the strength of the native educators is based exclusively in their pronunciation and the understanding of Englishspeaking culture, while the non-natives have as a strength the methodology and the didactics to guide the classes, from which one may draw a complementary relationship, in which one can find advantages and disadvantages. For that reason, the students who participated in this research think, and assure that learning a foreign language is not just a matter of speaking English well, this process implies practicing and three abilities more to be considered in order to become proficient languages learners. Students do not perceive there is just one way to move from a point to another one, they think there is a wide range of possibilities in terms of learning and nativeness is not the unique path but also self-motivation and abilities for the XXI century.

The students' descriptions of the implications of receiving English classes given by native educators reflect as a favorable aspect for their process the development of their speaking and listening ability, since the pronunciation is genuine and helps them to develop their listening, which in terms of learning English, makes up the input (what the students receive). While the implications with the non-native educators is reflected in the development of the abilities of reading and writing, since they cite understanding the topics better, learning the structural part of the language and the contextualization of the themes, the development of reading and writing, they are developing the output (what the student produces). Consequently, they maintain the premise that the strengths of one are the weaknesses of the other and vice-versa if it is a matter of a dichotomy, although they also perceive language learning guided by these two types of educators as a scaffolding process but what students really counts is the way how they might achieve their languages goals and learn, they are not concerned if their teachers are native or non-native speakers, they think that policies from some institutions and universities are more concerned about this aspect than students, last ones perceive classes with those educators as complementary process, both sides are different and good but a dichotomy is not an aspect students take into account when learning because for them it is more important to have a successful process than a biased one. The students claim that their goal is not to be a native-like speaker because they will not be and for that reason, they do not underestimate non-native educators, because they do not want to be perceived in future as the average speakers because of not having native similar pronunciation. Students do not think nonnative pronunciation is a fact to feel embarrassed. Classes taught by native educators are not a learning fact neither classes taught by a non-native educator are a failure. Native and non-native educators' classes are the opportunity to reach the same goal through different learning paths. In short words, the result of classes guided by these educators is not a dichotomy but a reciprocal process that might help students to find successful achievements in terms of language.

The educators interviewed, non-natives and natives of the English language, are conscious of their commitment and limitations to the students in terms of the teaching of English as a foreign language, more than assuming who would be more appropriate for the students, is the fact of analyzing the pedagogical practices and how these can be beneficial from the 
complementarity of the native and non-native educators, although, no-native ones know their limitations, those do not hope to be considered similar to natives either underestimated because of their cultural conditions. Additionally, it is important to keep in mind that we live in a globalized world that breaks barriers and borders and for that reason, we should be open to the world's different cultures.

\section{References Références Referencias}

1. Cáceres, O. (2014). Técnicas de investigación entrevista, encuesta y observación. Retrieved from https://es. slideshare.net/oscarcaceres9862/tecnicas -de-investigacion-entrevista-encuesta-y-observacin

2. Chacón, C. \& Perez, C. (2009). Acento y competencia lingüística: creencias de los educadores de inglés en formación.Retrieve from https://www.researchgate.net/publication/37795986 _Acento_y_competencia_linguistica_creencias_de_I os_educadores_de_ingles_en_formacion

3. Kachru, B. (2001). The other tongue. Urbana, IL: University of Illinois Press. Retrieved From https://www.press.uillinois.edu/books/catalog/38mb g8xr9780252062001.html

4. Kachru, B. and Nelson, C. L. (2001). World Englishes. In A. Burns and C. Coffin (Eds.), Analysing English in a global context: A reader (pp. 9-25). London and New York: Routledge in association with Macquarie University and The Open University. Retrieved from https://trove.nla.g ov. au/work/35670595? selectedversion $=$ NBD217128 09

5. Lasagabaster, D., Sierra, J. M. (2005). What do students think about the pros and cons of having a native-speaker teacher? In Llurda, E. (Ed.), Nonnative language teachers: Perceptions, challenges and contributions to the profession (pp. 217-242). New York, NY: Springer. Retrieved from https://journals.sagepub.com/doi/full/10.1177/21582 44014534451

6. Lakatos, S. y Ubach, A (1995) ¿Profesor nativo o no nativo?. Recuperado de ASELE Acta VI (1995) de http://cvc.cervantes.es/ensenanza/biblioteca_ele/as ele/pdf/06/06_0238.pdf

7. Manga, A. (2008). Lengua segunda (12) lengua extranjera (le): factores e incidencias de enseñanza/aprendizaje.

8. Martínez, P. (2006). El método de estudio de caso Estrategia metodológica de la investigación científica. Pensamiento y gestión. Retrieved from http://ciruelo.uninorte.edu.co/pdf/pensamiento_gesti on/20/5_El_metodo_de_estudio_de_caso.pd

9. Memoria de investigación. (s.f. pág. 56). Retrieved from http://emkt.funiber.org/2012/archivos/TFC/01MEMI-AspFormales-Esp_vOr1_20111104.pdf
10. MEN, COLOMBIA, Guía No. 22 Estándares Básicos de Competencias en Lenguas Extranjeras: inglés. Retrieved from http://www.mineducacion.gov.co/17 59/w3-article-115174.html

11. MEN, Colombia. Lineamientos Curriculares para el Área de Idiomas Extranjeros en la Educación Básica y Media (2006). Retrieved from http://www.mine ducacion.gov.co/1621/articles339975_recurso_7.pdf

12. MEN, COLOMBIA. Formar en lenguas extranjeras: iel reto!. Retrieved fromhttp://www.colombiaap rende.edu.co/html/mediateca/1607/articles115375 archivo.pdf

13. Muñoz, C. (2002). Aprender idiomas. Barcelona, España: Paidós Ibérica. Available in https://www.casadellibro.com/libroaprenderidiomas/ 9788449312953/857733

14. Paikeday, T. M. (2005). May I kill the native speaker?.TESOL Quarterly, 19, 390-395. Retrieved Fromhttps://www.jstor.org/stable/3586840?origin $=\mathrm{cr}$ ossref\&seq=2\#metadata_info_tab_contents

15. Peraza, Y., Saulny, Y., Arrioj, M., y Colmenares, C. (2012). El rol del profesor nativo desde la perspectiva del estudiante de inglés como lengua extranjera. Paradigma vol.33 no.2 Maracay. Retrieved from http://www.scielo.org.ve/scielo .php?script=sci_arttext\&pid $=$ S10112251201200020 0008

16. Santos, I. (2017): Lingüística aplicada a la enseñanza/aprendizaje del español como lengua extranjera. Madrid, Arco/Libros. Retrieved from http://www.arcomuralla.com/detalle_libro.php?id=42

17. Strauss, A., \& Corbin, J. (1994). Grounded theory methodology: An overview. In N. K. Denzin \& Y. S. Walkinshaw, I. \& Hoang, D. (2014). Native and NonNative English Language Teachers: Student Perceptions in Vietnam and Japan. Pág.1-9. 


\section{APPENDICES}

\section{Appendix 1}

\section{Questionnaire}

Objective. This questionnaire aims to collect information about the perceptions that students have in relation with English classes that will enable future teaching practices. Your answers will be treated confidentially with regard to the corresponding objective.

1. What is your perception about the process of learning English as a foreign language in the USTA?

2. From your point of view, what are the factors that influence the English learning process to be successful? Justify your answer. (Materials, teachers, environments, spaces, teaching resources, etc.)

3. How have your experiences with English as a foreign language classes been oriented by natives and non-natives in the USTA? Justify your answer.

4. What are the implications of taking English classes taught by native and non-native speakers at the USTA? Justify your answer.

5. In order for the learning process to be successful, classes should be taught by the native or non-native teacher? Justify your answer

6. How do you describe your learning process guided by a non-native teacher in the USTA?

7. What is your perception about native English professors in the USTA?

8. What is your perception about non-native English professors in the USTA?

9. What is the relationship between native and non-native teachers regarding their process of learning English as a foreign language in the USTA?

II part: Likert Questions.

Appendix 2

Interview

Please answer the following questions as honestly as possible. The product of the same will serve merely for academic and research purposes.

1. What is your academic position after taking English classes taught by native teachers at the USTA?

2. What is your academic position after taking an English class taught by non-native teachers at the

3. USTA?

4. How do you describe your English learning process guided by a native teacher at the USTA?

5. How do you describe your English learning process guided by a non-native teacher at the USTA?

6. From your point of view, what do you think are the implications of taking English classes taught bynative teachers at the USTA? Justify your answer.

7. From your point of view, what do you think are the implications of taking English classes taught by nonnative teachers? Justify your answer. 